\title{
Hypoxia Inducible Factor- $1 \alpha$ (HIF-1 $\alpha)$ Is Required for Neural Stem Cell Maintenance and Vascular Stability in the Adult Mouse SVZ
}

\author{
Lu Li, Kate M. Candelario, Kelsey Thomas, Ruth Wang, Kandis Wright, Amber Messier, and @Lee Anna Cunningham \\ Department of Neurosciences, University of New Mexico Health Sciences Center, School of Medicine, Albuquerque, New Mexico 87131
}

HIF- $1 \alpha$ is a hypoxia-inducible protein that regulates many cell and molecular processes, including those involved in angiogenesis and stem cell maintenance. Prior studies demonstrated constitutive HIF- $1 \alpha$ stabilization in neural stem cells (NSCs) of the adult mouse SVZ, but its role there has not been elucidated. Here, we tested the hypothesis that HIF- $1 \alpha$ plays an essential role in the maintenance of adult NSCs and stabilization of the SVZ vascular niche using conditional, tamoxifen-inducible Hifla knock-out mice. We generated nestin$\mathrm{CreER}^{\mathrm{T} 2} / \mathrm{R} 26 \mathrm{R}-\mathrm{YFP} / \mathrm{Hif1} \mathrm{a}^{\mathrm{fl} / \mathrm{fl}}$ triple transgenic mice, to enable tamoxifen-inducible Hifla gene inactivation in nestin-expressing NSCs within the adult SVZ. Hifla gene deletion resulted in a significant loss of YFP ${ }^{+}$NSCs within the SVZ by $45 \mathrm{~d}$ post recombination, which was preceded by significant regression of the SVZ vasculature at $14 \mathrm{~d}$, and concomitant decrease of VEGF expression by NSCs. Loss of $\mathrm{YFP}^{+}$NSCs following Hifla gene inactivation in vivo was likely an indirect consequence of vascular regression, since $\mathrm{YFP}^{+}$neurosphere formation over serial passage was unaffected. These results identify NSC-encoded HIF- $1 \alpha$ as an essential factor in the maintenance of the adult SVZ, and demonstrate that NSCs within the SVZ maintain the integrity of their vascular niche through HIF- $1 \alpha$-mediated signaling mechanisms.

Key words: hypoxia; stem cell niche; vasculature

\section{Introduction}

The adult rodent SVZ harbors a reservoir of multipotent neural stem cells (NSCs) capable of generating neurons, astrocytes, and oligodendrocytes throughout life (Alvarez-Buylla and GarciaVerdugo, 2002). Under nonpathological conditions, slowly dividing NSCs within the SVZ give rise to proliferative transit amplifying progenitors (TAPs), which then generate neuroblasts and postmitotic olfactory neurons. Under pathological conditions, SVZ-NSCs initiate multilineage regenerative responses important for aspects of plasticity, repair, and recovery from brain injury (Arvidsson et al., 2002; Li et al., 2010). Understanding the mechanisms that govern NSC maintenance within the SVZ is important for regenerative medicine in the CNS, since dysregulation can lead to imbalances in progenitor populations and depletion of the stem cell pool.

The microvasculature of the SVZ represents a critical regulator of stem cell function. NSCs reside in close proximity to blood vessels within the SVZ (Tavazoie et al., 2008) and receive signals from endothelial cells that direct stem cell renewal (Shen et al.,

\footnotetext{
Received Oct. 28, 2013; revised Oct. 29, 2014; accepted 0ct. 31, 2014.

Author contributions: L.L., K.M.C., and L.A.C. designed research; L.L., K.M.C., K.T., R.W., K.W., and A.M. performed research; L.L., K.M.C., and L.A.C. analyzed data; L.L. and L.A.C. wrote the paper.

This research was funded by the American Heart Association (12GRNT11660030 to L.A.C.). Images were generated using the University of New Mexico Cancer Center Fluorescence Microscopy Facility.

The authors declare no competing financial interests.

Correspondence should be addressed to Lee Anna Cunningham, Department of Neurosciences, MSC08 4740, 1 University of New Mexico, Albuquerque, NM 87131-0001. E-mail: leeanna@salud.unm.edu.

DOI:10.1523/JNEUROSCI.4590-13.2014

Copyright $\odot 2014$ the authors $\quad 0270-6474 / 14 / 3416713-07 \$ 15.00 / 0$
}

2004; Ramírez-Castillejo et al., 2006) and lineage progression (Kokovay et al., 2010). Likewise, stem cells regulate endothelial cell function, indicating bidirectional signaling (Louissaint et al., 2002). The vasculature as a critical component of the stem cell niche is not unique to the CNS, but contributes to stem cell maintenance across many organ systems and in the maintenance of CNS cancer stem cells (Calabrese et al., 2007).

Hypoxic signaling also plays an important role in stem cell maintenance (Panchision, 2009). Hypoxic characteristics of stem cells include constitutive stabilization of HIF- $1 \alpha$, a key transcriptional regulator of metabolism and angiogenesis. Although HIF- $1 \alpha$ normally undergoes proteasomal degradation under nonhypoxic conditions (Semenza, 2004), it is constitutively stabilized under aerobic conditions in a variety of stem cell types, including bone marrow hematopoietic stem cells (NombelaArrieta et al., 2013), mesenchymal stem cells (Palomäki et al., 2013), and NSCs (Mazumdar et al., 2010; Roitbak et al., 2011). We previously demonstrated that Hifla gene deletion impairs the vasculotrophic properties of embryonic and adult NSCs in cell culture and following intracerebral transplantation (Roitbak et al., 2008), suggesting that NSC-encoded HIF- $1 \alpha$ may function to stabilize the vascular niche through pro-angiogenic mechanisms, although this has not been previously investigated.

Here, we tested the hypothesis that NSC-encoded HIF- $1 \alpha$ plays an essential role in the maintenance of adult NSCs and stabilization of SVZ vasculature in situ using conditional, tamoxifen-inducible HIF- $1 \alpha$ knock-out mice. We demonstrate that induced Hifla gene deletion in adult NSCs results in their 


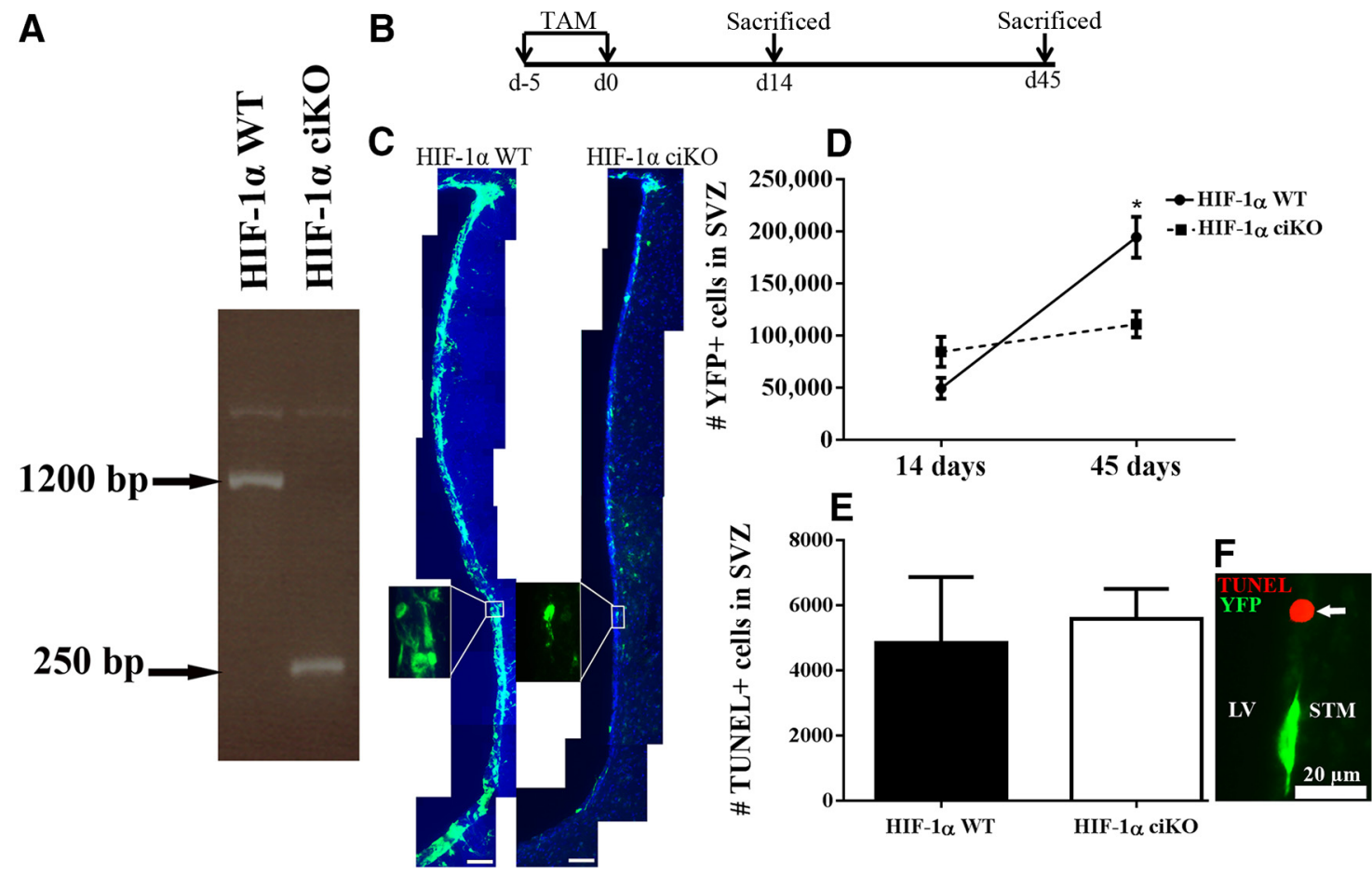

Figure 1. HIF- $1 \alpha$ is essential for maintenance of SVZ NSCS. A, Hif1a exon 2 deletion in YFP ${ }^{+}$cells isolated from SVZ of HIF- $1 \alpha$ WT and HIF- $1 \alpha$ ciKO mice. $\boldsymbol{B}$, Experimental time line. C, SVZ in the coronal plane $45 \mathrm{~d}$ following the final tamoxifen (TAM) injection. Merged images of YFP ${ }^{+}$cells (green) and DAPI (blue)-labeled nuclei. Inset shows higher power magnification of YFP ${ }^{+}$cells within the SVZ. Scale bar, $50 \mu \mathrm{m}$. D, YFP ${ }^{+}$cell number within the SVZ at 14 and $45 \mathrm{~d}$ post-tamoxifen treatment ( ${ }^{*} p<0.02, n=5$ mice/group/time point). $\boldsymbol{E}_{\text {, }}$ UUNEL ${ }^{+}$cells at $45 \mathrm{~d}$ post-tamoxifen treatment ( $n=5$ mice/group). $\boldsymbol{F}$, Representative TUNEL ${ }^{+}$image. LV, Lateral ventricle; STM, striatum.

gradual loss, which is preceded by regression of the SVZ vasculature. These findings identify NSC-HIF- $1 \alpha$ as a critical regulator of NSCs maintenance within the adult SVZ, and demonstrate that SVZ-NSCs maintain the integrity of their vascular niche through HIF- $1 \alpha$-mediated signaling mechanisms.

\section{Materials and Methods}

Mice

Animal experiments were performed in accordance with protocols approved by the University of New Mexico Animal Care and Use Committee. Nestin-CreER ${ }^{\mathrm{T} 2} / \mathrm{R} 26 \mathrm{R}-\mathrm{YFP} / H i f 1 a^{\mathrm{fl} / \mathrm{fl}} \quad$ (HIF-1 $\alpha$ ciKO) triple transgenic mice and nestin-CreER ${ }^{\mathrm{T} 2} / \mathrm{R} 26 \mathrm{R}-\mathrm{YFP} / \mathrm{Hifl} \mathrm{a}^{\mathrm{w} / \mathrm{w}}$ control (HIF-1 $\alpha$ WT) mice were generated, maintained and genotyped as previously described (Candelario et al., 2013).

\section{Tamoxifen administration}

Tamoxifen was prepared and administered as described previously (Candelario et al., 2013). Deletion of Hif1a exon 2 from YFP-sorted cells isolated from SVZ was confirmed using PCR as described previously (Candelario et al., 2013; Fig. 1A). Hifla exon 2 gene deletion abolishes HIF- $1 \alpha$ transcriptional activity within $\mathrm{YFP}^{+}$NSCs, as previously demonstrated using a hypoxia response element binding assay (Harms et al., 2010). For neurosphere assays, tamoxifen was administered as a single dose at postnatal day $3(\mathrm{P} 3 ; 33 \mathrm{mg} / \mathrm{kg})$ and mice were killed at P11. For all other experiments, tamoxifen ( $180 \mathrm{mg} / \mathrm{kg}$, i.p.) was administered to 6- to 8 -week-old male mice daily for 5 consecutive days and mice were killed $14 \mathrm{~d}$ or $45 \mathrm{~d}$ after the final tamoxifen dose.

Immunohistochemistry. Immunofluorescent staining of histological brain sections was performed as described previously (Li et al., 2010), with the following primary antibodies: goat anti-doublecortin (DCX; 1:200; Santa Cruz Biotechnology), mouse anti- GFAP (1:500; Sigma), rabbit anti-Glut-1 (1:200; Abcam), rabbit anti-laminin (1:500; Sigma), chicken anti-GFP (1:1000; Invitrogen), rabbit anti-S100 $\beta$ (1:500; DAKO), rat anti-BrdU (1:250; Accurate), rabbit anti-Ki67 (1:1000; Leica Microsystems), and rabbit anti-VEGF (1:200; Santa Cruz Biotechnology). TUNEL staining was performed using the NeuroTACS II kit
(Trevigen) according to the manufacturer's protocol as described previously (Kokovay et al., 2006). SVZ whole-mount dissection and staining were performed as described previously (Mirzadeh et al., 2010) and imaged using a Zeiss 510 laser scanning confocal microscope.

\section{Stereology}

Cell counting and phenotype analysis. The number of $\mathrm{YFP}^{+}$cells within the SVZ was estimated using Optical Fractionator Stereo Investigator software (MicroBrightField) linked to an Olympus DSU spinning disk confocal microscope. The contour of the SVZ was manually outlined in each histological section used for counting, using a $20 \times$ objective. A total of six coronal sections per mouse, spaced $240 \mu \mathrm{m}$ apart, located between $+1.32 \mathrm{~mm}$ anterior and $-0.22 \mathrm{~mm}$ posterior to bregma, were used for analysis. The counting frame size was $30 \times 30 \mu \mathrm{m}$ and grid size was $120 \times$ $120 \mu \mathrm{m}$. For phenotype analysis, the number of YFP ${ }^{+}$cells within $35 \mu \mathrm{m}$ from the edge of lateral ventricle that coexpressed each phenotypic marker was determined using the same method.

Vascular density. Blood vessel density was quantified as published previously (van Praag et al., 2005). A total of six coronal sections per mouse, spaced $240 \mu \mathrm{m}$ apart, were used for analysis. The optical fractionator (Stereo Investigator; MicroBrightField) was used to estimate blood vessel number. The counting frame was $50 \times 50 \mu \mathrm{m}$ and the grid size was $100 \times$ $100 \mu \mathrm{m}$. In cases where blood vessels had multiple branches, each branch was counted as one additional vessel. The total number of lamininpositive blood vessels was divided by the total volume to give an estimate of density.

\section{Serial neurosphere formation assay}

SVZs were dissected from P11 mice, $8 \mathrm{~d}$ following tamoxifen administration, and plated in uncoated tissue culture plates as described previously (Candelario et al., 2013). Neurospheres were maintained in Neurobasal medium (Invitrogen) supplemented with B-27 (2\%; Invitrogen), glutamine (2.0 mM; Sigma), penicillin ( $100 \mathrm{U} / \mathrm{ml}$; Invitrogen), streptomycin (100 $\mu \mathrm{g} / \mathrm{ml}$; Invitrogen), EGF (10 ng/ml; Invitrogen), and bFGF $(20$ $\mathrm{ng} / \mathrm{ml}$; Invitrogen). Neurospheres were passaged every $8 \mathrm{~d}$ by enzymatic dissociation with Accutase (Sigma) and subcultured at $1.4 \times 10^{4}$ cells/ 



Figure 2. Phenotypic analysis of YFP ${ }^{+}$NSC. $A-C$, Confocal images with orthogonal views (left) and quantitative comparisons (right) for $\operatorname{NSCS}(\boldsymbol{A}), \operatorname{TAPs}(\boldsymbol{B})$, and neuroblasts $(\boldsymbol{C})$ at $45 \mathrm{~d}$ post-tamoxifen treatment $\left({ }^{*} p<0.02,{ }^{* *} p<0.001, n=5\right.$ mice/group).

$\mathrm{cm}^{2}$ in 6-well tissue culture plates. Before each passage the number of $\mathrm{YFP}^{+}$neurospheres $150-200 \mu \mathrm{m}$ in diameter were scored across 20 randomly chosen $1 \mathrm{~mm}^{2}$ counting frames per well using an Olympus inverted fluorescence microscope and a $20 \times$ objective.

\section{Statistical analysis}

Data are expressed as means \pm SEM. Statistical comparisons were made using Student's $t$ tests, with $p<0.05$ considered statistically significant.

\section{Results}

HIF- $1 \alpha$ is required for the maintenance of neural stem and progenitor cells within the adult SVZ

To examine the effects of Hifla gene deletion on NSCs within the adult SVZ, we treated adult HIF- $1 \alpha$ WT and HIF- $1 \alpha$ ciKO mice with tamoxifen for 5 consecutive days, and compared the number of $\mathrm{YFP}^{+}$cells at 14 and $45 \mathrm{~d}$ following the final tamoxifen injection (Fig. 1). $\mathrm{YFP}^{+}$ cells were observed throughout the dorsoventral extent of the anterolateral SVZ in both HIF- $1 \alpha$ WT and HIF- $1 \alpha$ ciKO mice at $45 \mathrm{~d}$ post tamoxifen (Fig. $1 C$ ); however, Hifla gene deletion abolished the expansion of $\mathrm{YFP}^{+}$cells over time in HIF- $1 \alpha$ ciKO mice compared with controls. As shown in Figure $1 D$, the number of YFP ${ }^{+}$ cells increased significantly $(\sim 4$-fold) between 14 and $45 \mathrm{~d}$ post tamoxifen in HIF- $1 \alpha$ WT, but not in HIF- $1 \alpha$ ciKO mice. By $45 \mathrm{~d}$ post tamoxifen, the number of YFP ${ }^{+}$cells within the SVZ of HIF- $1 \alpha$ ciKO mice was decreased by $50 \%$ compared with control mice $(p<0.01)$. To determine whether the lower number of $\mathrm{YFP}^{+}$cells in HIF- $1 \alpha$ ciKO mice was due to increased cell death by apoptosis, we compared the number of TUNEL ${ }^{+}$cells within the SVZ of both genotypes. We found no difference in the number of TUNEL $^{+}$cells at either $14 \mathrm{~d}$ (data not shown) or $45 \mathrm{~d}$ post tamoxifen (Fig. 1E).

Hif1 $a$ gene deletion results in gradual depletion of NSCs within adult SVZ Nestin is expressed within primitive NSCs, TAPs, and early proliferating neuroblasts within the adult SVZ (Pastrana et al., 2009). To determine which cell type is primarily affected by Hifla gene deletion, we surveyed $\mathrm{YFP}^{+}$cells at $45 \mathrm{~d}$ post tamoxifen for coexpression of markers to identify specific cell types as described (Ables et al., 2010). NSCs were identified by the expression of GFAP in the absence of the mature astrocyte marker, $\mathrm{S} 100 \beta$; TAPs were identified by the presence of the cell cycle marker, Ki67 and the absence of the neuroblast marker, DCX; and neuroblasts were identified using DCX. As shown in Figure 2, Hifla gene deletion in nestin ${ }^{+}$ cells resulted in marked reduction in the number of $\mathrm{YFP}^{+}$NSCs and TAPs compared with control mice. $\mathrm{YFP}^{+}$NSCs were decreased by $82 \%$ in HIF- $1 \alpha$ ciKO mice compared with controls (4657 \pm 1960 vs $26,199 \pm 8220$, respectively; $p<0.01$ ). The mean number of YFP ${ }^{+}$ TAPs was decreased by $58 \%$ (6871 \pm 872 vs $16,501 \pm 6307, p<$ 0.02 ). The approximate $25 \%$ decrease in the mean number of $\mathrm{YFP}^{+}$ neuroblasts at $45 \mathrm{~d}$ following Hifla gene deletion did not reach statistical significance $(p=0.06)$. 
Hifla gene deletion also resulted in a significant decrease in the percentage of all YFP ${ }^{+}$cells represented by NSCs at $45 \mathrm{~d}$ post tamoxifen $(13.2 \pm 2.9$ vs $4.1 \pm 1.3 \%$ of all $\mathrm{YFP}^{+}$cells were NSCs in HIF- $1 \alpha$ WT vs HIF- $1 \alpha$ ciKO mice, respectively; $p<0.01)$. Although the percentage of $\mathrm{YFP}^{+}$cells represented by neuroblasts appeared to increase by $\sim 8 \%$ at $45 \mathrm{~d}$ following Hifla gene inactivation, this increase did not reach statistical significance $(32.3 \pm 3.1$ vs $40.9 \pm 6.2 \%, p=0.12)$; there was no significant difference in the proportion of $\mathrm{YFP}^{+}$cells represented by TAPs $(8.2 \pm 2.4$ vs $6.2 \pm 0.1 \%$ in HIF- $1 \alpha$ WT vs HIF- $1 \alpha$ ciKO mice, respectively; $p=0.10)$. The percentage of $\mathrm{YFP}^{+}$cells undergoing proliferation at the time of being killed was not different between strains, as assessed by Ki67 immunofluorescence $(11.8 \pm 1.9$ and $12.0 \pm 2.9 \%$ in HIF- $1 \alpha$ WT vs HIF- $1 \alpha$ ciKO mice, $p=$ $0.90)$. These results suggest that the gradual depletion of YFP ${ }^{+}$nestin-lineage cells following Hifla gene deletion is not due to an overall impairment of proliferation, but primarily involves depletion of upstream NSCs.

Hifla gene deletion results in loss of BrdU label-retaining NSCs within the adult SVZ, but has no effect on capacity for neurosphere formation ex vivo To label slowly dividing NSCs, we used a BrdU label-retaining assay whereby mice were treated with tamoxifen for 5 consecutive days followed by BrdU in their drinking water $(0.8 \mathrm{mg} / \mathrm{ml})$ continuously for 2 weeks. After a $12 \mathrm{~d}$ BrdU washout period, mice were analyzed for numbers of BrdU label-retaining cells situated within $35 \mu \mathrm{m}$ of the lateral ventricle (Figure $3 A$ ). In agreement with our phenotype analysis, the number of $\mathrm{BrdU}^{+} / \mathrm{YFP}^{+}$colabeled cells was significantly decreased by $\sim 60 \%$ in HIF- $1 \alpha$ ciKO mice compared with controls $(651 \pm 141$ vs $1601 \pm 284$ colabeled cells, respectively; $p<0.01$; Fig. $3 B$ ). However, the capacity for $\mathrm{YFP}^{+}$NSC self-renewal ex vivo was not affected by Hifla gene deletion, as indicated by formation of $\mathrm{YFP}^{+} \mathrm{SVZ}$ neurospheres generated from tamoxifen-treated HIF- $1 \alpha$ WT and HIF- $1 \alpha$ ciKO mice (Fig. 3C,D). These data suggest that NSC-encoded HIF- $1 \alpha$ may act indirectly to regulate NSC maintenance and self-renewal in vivo.

\section{HIF- $1 \alpha$ is essential for SVZ vascular stability}

HIF- $1 \alpha$ activates the transcription of VEGF and other angiogenic growth factor genes and is required for vasculature development. Previous studies demonstrated that NSCs support the survival of endothelial cells in culture and following transplantation through HIF-1 $\alpha$-VEGF signaling pathways (Roitbak et al., 2008). To determine whether HIF- $1 \alpha$ gene expression by NSCs is essential for maintaining vascular stability within the adult SVZ in situ, we quantified microvascular density within the SVZ of both HIF- $1 \alpha$ ciKO and HIF- $1 \alpha$ WT mice using immunofluorescence for laminin or glucose transporter-1 (Glut-1). As shown in Figure 4 , microvascular density was significantly decreased by $\sim 50 \%$ in
HIF- $1 \alpha$ ciKO compared with HIF- $1 \alpha$ WT mice at both 14 and $45 \mathrm{~d}$ post tamoxifen administration. At 2 weeks, the density of blood vessels within the SVZ of HIF- $1 \alpha$ WT mice $\left(1.73 \times 10^{-4} \pm\right.$ $0.32 \times 10^{-4} / \mu \mathrm{m}^{3}$ ) was significantly greater than that in HIF- $1 \alpha$ ciKO mice $\left(1.03 \times 10^{-4} \pm 0.15 \times 10^{-4} / \mu \mathrm{m}^{3}\right)$, and this difference was maintained at $45 \mathrm{~d}$ post tamoxifen $(p<0.01)$. The reduced vascular density at 2 weeks post tamoxifen was also apparent in whole-mount preparations of adult SVZ in which the vasculature was visualized using immunofluorescence for Glut-1 (Fig. 4B). Importantly, blood vessel density within striatum was not decreased within striatum of HIF- $1 \alpha$ ciKO mice $\left(2.4 \times 10^{-5}\right.$ $\pm 8.7 \times 10^{-7}$ vs $2.6 \times 10^{-5} \pm 1.8 \times 10^{-6}$ in HIF- $1 \alpha \mathrm{WT}$ vs HIF- $1 \alpha$ ciKO, respectively; $p=0.44, n=5$ mice per group), indicating that Hifla gene inactivation within NSCs does not impact the vasculature outside the SVZ.

\section{Hifla gene inactivation impairs VEGF expression}

Based on prior studies demonstrating impaired VEGF production following Hifla gene silencing in cultured NSCs (Harms et al., 2010), we compared VEGF production in $\mathrm{YFP}^{+}$cells from HIF- $1 \alpha$ ciKO and HIF- $1 \alpha$ WT mice at 2 weeks following tamoxifen-induced recombination. As shown in Figure 4, E and $F$, robust VEGF immunofluorescence was observed within SVZ $\mathrm{YFP}^{+}$NSCs in HIF- $1 \alpha$ WT mice, but not within the majority of $\mathrm{YFP}^{+}$NSCs in HIF- $1 \alpha$ ciKO mice. These observations suggest that Hifla gene deletion leads to a downregulation of VEGF production in adult SVZ-NSCs, which may underlie impaired vascular stability. 
A



B



C
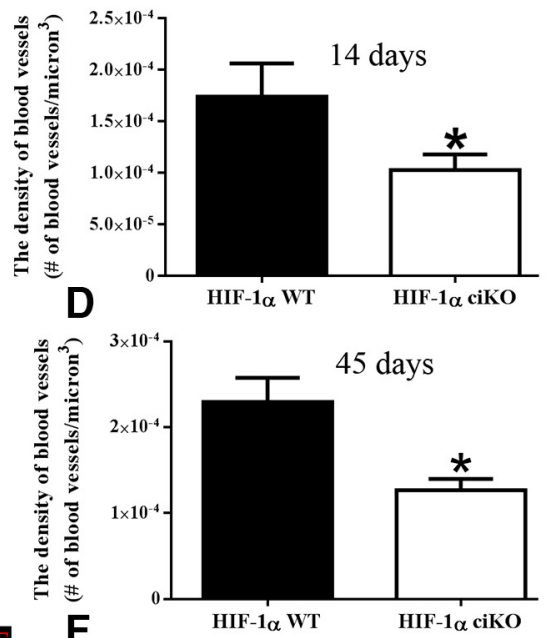



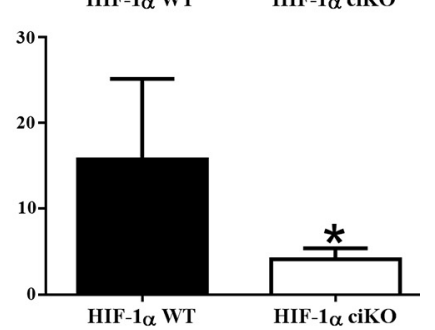

Figure 4. HIF-1 $\alpha$ is essential for maintenance of SVZ vasculature. A, Montage of coronal section through the SVZ demonstrating dual immunofluorescence for YFP (green), and laminin (red) from HIF- $1 \alpha$ WT and Hif- $1 \alpha$ ciKO mice at $45 \mathrm{~d}$ post tamoxifen, counterstained with DAPI nuclear label (blue). Scale bar, $50 \mu \mathrm{m}$. B, Glut- 1 immunofluorescence of vasculature within SVZ whole-mount preparation from HIF- $1 \alpha$ WT and HIF- $1 \alpha$ ciKO mice 45 d following tamoxifen injection. C, D, Quantification of blood vessel density within the SVZ of HIF- $1 \alpha$ WT versus HIF- $1 \alpha$ ciKO at 14 and $45 \mathrm{~d}$ post-tamoxifen injection ( ${ }^{*} p<0.02, n=5$ mice/group). E, Dual immunofluorescence for YFP (green) and VEGF (red) within SVZ of Hif- $1 \alpha$ WT (left) and HIF- $1 \alpha$ ciKO (right) mice. F, Quantification of VEGF immunofluorescence within YFP ${ }^{+}$cells $(p<0.05 ; n=5$ mice/group).

\section{Discussion}

These studies demonstrate that HIF- $1 \alpha$ expression is required for the maintenance of NSCs within the adult SVZ and vascularity within the stem cell niche. Conditional and inducible Hifla gene deletion in nestin ${ }^{+}$cells resulted in a gradual depletion of YFP ${ }^{+}$ NSCs and TAPs over the course of several weeks, preceded by SVZ vascular regression. That Hifla gene deletion within nestin ${ }^{+}$ cells first resulted in vascular regression followed by depletion of NSCs and downstream TAPs, suggests a potential indirect role of NSC-encoded HIF- $1 \alpha$ in neural stem cell maintenance secondary to stabilization of the vascular niche.

Utilizing a combination of phenotypic fate analysis coupled with a long-term BrdU label-retaining assay, we show that the gradual loss of YFP ${ }^{+}$cells over time was most likely due to initial depletion of upstream NSCs with subsequent diminishment of downstream progenitors. Hifla gene deletion in nestin ${ }^{+}$cells resulted in an $82 \%$ loss of $\mathrm{YFP}^{+} \mathrm{NSC}^{+}$and a $58 \%$ loss of $\mathrm{YFP}^{+}$ TAPs by $45 \mathrm{~d}$ following tamoxifen-induced recombination. Although the number of neuroblasts was also reduced by $\sim 25 \%$, this did not reach statistical significance by $45 \mathrm{~d}$. The reduction in the number of TAPs was likely a consequence of upstream NSC loss, since the percentage of $\mathrm{YFP}^{+}$cells that represented NSCs was decreased $\sim 3$-fold, whereas the percentage of $\mathrm{YFP}^{+}$cells representing TAPs and neuroblasts remained unchanged or slightly increased. Hif1a gene deletion also resulted in a 2- to 3-fold loss of BrdU label-retaining cells. The loss of YFP ${ }^{+}$cells within the SVZ following Hifla gene deletion was not due to cell death, as assessed by TUNEL, or to an overall reduction in cell proliferation, since there was no change in the percentage of
$\mathrm{YFP}^{+}$cells expressing the proliferation marker Ki67. These results suggest that Hifla gene deletion may slow the expansion of NSCs, possibly through altering the mode of self-renewing cell divisions, without altering overall proliferation rate or cell death. We observed no significant decrease in the number of $\mathrm{YFP}^{+}$ neuroblasts or $\mathrm{YFP}^{+}$cells within the olfactory bulb (data not shown), which could be explained by that fact that downstream depletion of these cell populations may require several months following the gradual loss of upstream NSCs (Imayoshi et al., 2010).

Loss of NSCs within the SVZ of HIF- $1 \alpha$ ciKO was preceded by vascular regression, suggesting that the loss of NSCs could be secondary to destabilization of the SVZ vasculature. The importance of SVZ vasculature for maintenance of neural stem cells and lineage progression within the SVZ has been well documented (Shen et al., 2004, 2008; Tavazoie et al., 2008; Kokovay et al., 2010). Pigment epithelial-derived factor (PEDF) may mediate these effects, at least in part, since it is expressed by SVZ endothelial cells and promotes Notch-dependent self-renewal of NSCs (Andreu-Agulló et al., 2009). Furthermore, endothelial-derived PEDF maintains the NSC population within the SVZ by directing the mode of self-renewing divisions rather than regulating proliferation rate (Andreu-Agulló et al., 2009). In addition, stromal derived factor- 1 is another endothelial mediator that directs NSC activation (Kokovay et al., 2010), and its receptor is a known target of HIF-1 (Zagzag et al., 2006). Thus, depletion of YFP ${ }^{+}$ cells within the SVZ following Hif1a gene deletion may be secondary to vascular regression, as opposed to a cell-autonomous 
effect of Hifla gene deletion within NSCs, particularly since ex vivo neurosphere propagation was not affected.

The paracrine signaling mechanisms by which NSC-encoded HIF- $1 \alpha$ maintains vascular stability within the SVZ are likely due to sustained transcriptional activation of VEGF or other angiogenic signaling molecules. Stabilized HIF- $1 \alpha$ forms a heterodimeric complex with HIF- $1 \beta$ to create HIF-1, which is a potent transcriptional activator of VEGF and other angiogenic factors (Simon and Keith, 2008). Indeed, conditional deletion of HIF- $1 \alpha$ in embryonic nestin-expressing stem cells of the developing nervous system results in regression of vasculature and loss of neural cells (Tomita et al., 2003). We have previously demonstrated that NSCs are vasculotrophic and support the survival of endothelial cells in culture and following intracerebral transplantation through HIF- $1 \alpha$-regulated VEGF signaling (Roitbak et al., 2008). The present studies extend those findings to show that NSCs also support the SVZ vasculature in situ, and that Hifla gene deletion in the adult SVZ impairs VEGF expression. It is noteworthy that Yuen et al. (2014) recently demonstrated coupling of oligodendrocyte progenitor-encoded HIF function with angiogenesis and myelination in developing CNS white matter, mediated in part by HIF-regulated Wnt signaling (Yuen et al., 2014).

The mechanisms that maintain HIF- $1 \alpha$ stabilization and function within SVZ-NSCs are currently unclear. Within the adult rodent SVZ, HIF- $1 \alpha$ expression is localized to NSCs (nestin ${ }^{+}$, Sox $-2^{+}$, and $\mathrm{GFAP}^{+}$) but is not expressed in $\mathrm{DCX}^{+}$neuroblasts (Roitbak et al., 2011). Although the SVZ is highly vascularized, it should be noted that cellular oxygen levels within this niche environment have been estimated to be $\sim 2.5-3.0 \%$ under nonpathological conditions (Santilli et al., 2010). Furthermore, high levels of ROS are maintained within NSCs, which is important for the regulation of self-renewal, and may stabilize HIF-1 activity through the mTOR pathway (Le Belle et al., 2011). Additional $\mathrm{O}_{2}$-independent mechanisms for HIF- $1 \alpha$ stabilization occur under physiological conditions that can be activated by calcium-regulated signaling events, growth factors, and cytokines that are likely present within the stem cell niche (for review, see (Majmundar et al., 2010).

Overall, our study describes a novel regulatory mechanism for the maintenance of NSCs and their perivascular SVZ niche through NSC-encoded HIF- $1 \alpha$. Ultimately, small molecule regulators that target HIF- $1 \alpha$ may be useful in promoting the integrity of the stem cell niche and maintenance of the stem cell pool under aging and pathological conditions, thereby ensuring an adequate supply of endogenous NSCs for regenerative purposes.

\section{References}

Ables JL, Decarolis NA, Johnson MA, Rivera PD, Gao Z, Cooper DC, Radtke F, Hsieh J, Eisch AJ (2010) Notch1 is required for maintenance of the reservoir of adult hippocampal stem cells. J Neurosci 30:10484-10492. CrossRef Medline

Alvarez-Buylla A, Garcia-Verdugo JM (2002) Neurogenesis in adult subventricular zone. J Neurosci 22:629-634. Medline

Andreu-Agulló C, Morante-Redolat JM, Delgado AC, Fariñas I (2009) Vascular niche factor PEDF modulates Notch-dependent stemness in the adult subependymal zone. Nat Neurosci 12:1514-1523. CrossRef Medline

Arvidsson A, Collin T, Kirik D, Kokaia Z, Lindvall O (2002) Neuronal replacement from endogenous precursors in the adult brain after stroke. Nat Med 8:963-970. CrossRef Medline

Calabrese C, Poppleton H, Kocak M, Hogg TL, Fuller C, Hamner B, Oh EY, Gaber MW, Finklestein D, Allen M, Frank A, Bayazitov IT, Zakharenko SS, Gajjar A, Davidoff A, Gilbertson RJ (2007) A perivascular niche for brain tumor stem cells. Cancer Cell 11:69-82. CrossRef Medline

Candelario KM, Shuttleworth CW, Cunningham LA (2013) Neural stem/ progenitor cells display a low requirement for oxidative metabolism independent of hypoxia inducible factor-1alpha expression. J Neurochem 125:420-429. CrossRef Medline

Harms KM, Li L, Cunningham LA (2010) Murine neural stem/progenitor cells protect neurons against ischemia by HIF-1alpha-regulated VEGF signaling. PLoS One 5:e9767. CrossRef Medline

Imayoshi I, Sakamoto M, Yamaguchi M, Mori K, Kageyama R (2010) Essential roles of Notch signaling in maintenance of neural stem cells in developing and adult brains. J Neurosci 30:3489-3498. CrossRef Medline

Kokovay E, Li L, Cunningham LA (2006) Angiogenic recruitment of pericytes from bone marrow after stroke. J Cereb Blood Flow Metab 26:545555. CrossRef Medline

Kokovay E, Goderie S, Wang Y, Lotz S, Lin G, Sun Y, Roysam B, Shen Q, Temple S (2010) Adult SVZ lineage cells home to and leave the vascular niche via differential responses to SDF1/CXCR4 signaling. Cell Stem Cell 7:163-173. CrossRef Medline

Le Belle JE, Orozco NM, Paucar AA, Saxe JP, Mottahedeh J, Pyle AD, Wu H, Kornblum HI (2011) Proliferative neural stem cells have high endogenous ROS levels that regulate self-renewal and neurogenesis in a PI3K/ Akt-dependent manner. Cell Stem Cell 8:59-71. CrossRef Medline

Li L, Harms KM, Ventura PB, Lagace DC, Eisch AJ, Cunningham LA (2010) Focal cerebral ischemia induces a multilineage cytogenic response from adult subventricular zone that is predominantly gliogenic. Glia 58:1610 1619. CrossRef Medline

Louissaint A Jr, Rao S, Leventhal C, Goldman SA (2002) Coordinated interaction of neurogenesis and angiogenesis in the adult songbird brain. Neuron 34:945-960. CrossRef Medline

Majmundar AJ, Wong WJ, Simon MC (2010) Hypoxia-inducible factors and the response to hypoxic stress. Mol Cell 40:294-309. CrossRef Medline

Mazumdar J, O’Brien WT, Johnson RS, LaManna JC, Chavez JC, Klein PS, Simon MC (2010) O2 regulates stem cells through Wnt/beta-catenin signalling. Nat Cell Biol 12:1007-1013. CrossRef Medline

Mirzadeh Z, Doetsch F, Sawamoto K, Wichterle H, Alvarez-Buylla A (2010) The subventricular zone en-face: wholemount staining and ependymal flow. J Vis Exp pii:1938. CrossRef Medline

Nombela-Arrieta C, Pivarnik G, Winkel B, Canty KJ, Harley B, Mahoney JE, Park SY, Lu J, Protopopov A, Silberstein LE (2013) Quantitative imaging of haematopoietic stem and progenitor cell localization and hypoxic status in the bone marrow microenvironment. Nat Cell Biol 15:533-543. CrossRef Medline

Palomäki S, Pietilä M, Laitinen S, Pesälä J, Sormunen R, Lehenkari P, Koivunen P (2013) HIF-1alpha is upregulated in human mesenchymal stem cells. Stem Cells 31:1902-1909. CrossRef Medline

Panchision DM (2009) The role of oxygen in regulating neural stem cells in development and disease. J Cell Physiol 220:562-568. CrossRef Medline

Pastrana E, Cheng LC, Doetsch F (2009) Simultaneous prospective purification of adult subventricular zone neural stem cells and their progeny. Proc Natl Acad Sci U S A 106:6387-6392. CrossRef Medline

Ramírez-Castillejo C, Sánchez-Sánchez F, Andreu-Agulló C, Ferrón SR, Aroca-Aguilar JD, Sánchez P, Mira H, Escribano J, Fariñas I (2006) Pigment epithelium-derived factor is a niche signal for neural stem cell renewal. Nat Neurosci 9:331-339. CrossRef Medline

Roitbak T, Li L, Cunningham LA (2008) Neural stem/progenitor cells promote endothelial cell morphogenesis and protect endothelial cells against ischemia via HIF-1alpha-regulated VEGF signaling. J Cereb Blood Flow Metab 28:1530-1542. CrossRef Medline

Roitbak T, Surviladze Z, Cunningham LA (2011) Continuous Expression of HIF-1alpha in Neural Stem/Progenitor Cells. Cell Mol Neurobiol 31: 119-133. CrossRef Medline

Santilli G, Lamorte G, Carlessi L, Ferrari D, Rota Nodari L, Binda E, Delia D, Vescovi AL, De Filippis L (2010) Mild hypoxia enhances proliferation and multipotency of human neural stem cells. PLoS One 5:e8575. CrossRef Medline

Semenza GL (2004) Hydroxylation of HIF-1: oxygen sensing at the molecular level. Physiology 19:176-182. CrossRef Medline

Shen Q, Goderie SK, Jin L, Karanth N, Sun Y, Abramova N, Vincent P, Pumiglia K, Temple S (2004) Endothelial cells stimulate self-renewal and expand neurogenesis of neural stem cells. Science 304:1338-1340. CrossRef Medline

Shen Q, Wang Y, Kokovay E, Lin G, Chuang SM, Goderie SK, Roysam B, Temple S (2008) Adult SVZ stem cells lie in a vascular niche: a quanti- 
tative analysis of niche cell-cell interactions. Cell Stem Cell 3:289-300. CrossRef Medline

Simon MC, Keith B (2008) The role of oxygen availability in embryonic development and stem cell function. Nat Rev Mol Cell Biol 9:285-296. CrossRef Medline

Tavazoie M, Van der Veken L, Silva-Vargas V, Louissaint M, Colonna L, Zaidi B, Garcia-Verdugo JM, Doetsch F (2008) A specialized vascular niche for adult neural stem cells. Cell Stem Cell 3:279-288. CrossRef Medline

Tomita S, Ueno M, Sakamoto M, Kitahama Y, Ueki M, Maekawa N, Sakamoto H, Gassmann M, Kageyama R, Ueda N, Gonzalez FJ, Takahama Y (2003) Defective brain development in mice lacking the Hif-1alpha gene in neural cells. Mol Cell Biol 23:6739-6749. CrossRef Medline van Praag H, Shubert T, Zhao C, Gage FH (2005) Exercise enhances learning and hippocampal neurogenesis in aged mice. J Neurosci 25:86808685. CrossRef Medline

Yuen TJ, Silbereis JC, Griveau A, Chang SM, Daneman R, Fancy SP, Zahed H, Maltepe E, Rowitch DH (2014) Oligodendrocyte-encoded HIF function couples postnatal myelination and white matter angiogenesis. Cell 158: 383-396. CrossRef Medline

Zagzag D, Lukyanov Y, Lan L, Ali MA, Esencay M, Mendez O, Yee H, Voura EB, Newcomb EW (2006) Hypoxia-inducible factor 1 and VEGF upregulate CXCR4 in glioblastoma: implications for angiogenesis and glioma cell invasion. Lab Invest 86:1221-1232. CrossRef Medline 